Original Article

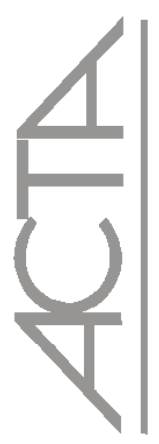

\title{
Telling family stories: learning strategies in family care*
}

\author{
Contando histórias familiares: estratégias de aprendizagem no cuidado com família \\ Contando historias familiares: estrategias de aprendizaje en el cuidado a la familia
}

\author{
Ana Lúcia de Moraes Horta ${ }^{1}$, Mônica Zagallo Camargo ${ }^{2}$, Maria Goreti da Silva \\ Cruz $^{3}$, Celina Daspett ${ }^{4}$
}

\begin{abstract}
Objective: To identify how nursing students experience telling their family stories as a learning strategy in family care. Methods: This was a qualitative and descriptive study, conducted with 18 students (second year, Nursing undergraduate course, Federal University of São Paulo) who participated in four meetings. These were used as an additional resource in formation of family care. Content analysis as proposed by Bardin was used. Results: Three categories emerged: changes in perception and expansion of the concept of family, and redefinition of ties; identification of similarities, beliefs, values, and rituals in family stories; enhancement of active listening as a strategy for family care. Conclusion: This study contributed to create new strategies for nursing education in family care so far as students could revise concepts and extend contexts based on stories told by participants.
\end{abstract}

Keywords: Education, nursing; Family health; Autobiography

\section{RESUMO}

Objetivo: Identificar como os estudantes de enfermagem vivenciam o contar de suas histórias familiares, como estratégia de aprendizagem no cuidado com a família. Métodos: Estudo qualitativo, descritivo realizado com 18 estudantes do $2^{\circ}$ ano do Curso de graduação em Enfermagem da Universidade Federal de São Paulo que participaram de quatro encontros, utilizados como recurso complementar na formação do cuidado com a família. Utilizou-se a análise de conteúdo proposta por Bardin. Resultados: Emergiram três categorias: mudanças na percepção e ampliação do conceito de família e ressignificação de vínculos; identificação de semelhanças, crenças, valores e rituais nas histórias familiares; valorização da escuta ativa, como uma estratégia do cuidado com família. Conclusão: O estudo contribuiu para a criação de novas estratégias de formação em enfermagem no cuidado com família à medida que as alunas puderam rever conceitos e ampliar contextos com base nas histórias contadas pelas participantes.

Descritores: Educação em enfermagem; Saúde da família; Autobiografia

\section{RESUMEN}

Objetivo: Identificar cómo los estudiantes de enfermería vivencian el relato de sus historias familiares, como estrategia de aprendizaje en el cuidado a la familia. Métodos: Estudio cualitativo, descriptivo realizado con 18 estudiantes del $2^{\circ}$ año del Pregrado en Enfermería de la Universidad Federal de Sao Paulo que participaron de cuatro encuentros, utilizados como recurso complementario en la formación del cuidado a la familia. Se utilizó el análisis de contenido propuesto por Bardin. Resultados: Emergieron tres categorías: cambios en la percepción y ampliación del concepto de familia y resignificación de vínculos; identificación de semejanzas, creencias, valores y rituales en las historias familiares; valorización de la escucha activa, como una estrategia del cuidado a la familia. Conclusión: El estudio contribuyó para la creación de nuevas estrategias de formación en enfermería en el cuidado a la familia en la medida que las alumnas pudieran revisar conceptos y ampliar contextos con base en las historias contadas por las participantes.

Descriptores: Educación em enfermería; Salud de la família; Autobiografía

\footnotetext{
* Study developed by Group for Study and Research in Family and Community, Federal University of São Paulo, UNIFESP. Graduate Program, Escola Paulista de Enfermagem, Federal University of São Paulo, UNIFESP, São Paulo, SP, Brażil.

${ }^{1}$ PhD in Nursing. Adjunct Professor, Undergraduate and Graduate Courses, Discipline of Public Health, Escola Paulista de Enfermagem, Federal University of São Paulo, UNIFESP, São Paulo, SP, Brazil.

${ }^{2}$ Graduate (MSc) student. Graduate Program, Escola Paulista de Enfermagem, Federal University of São Paulo, UNIFESP, São Paulo, SP, Brazil.

${ }^{3}$ Graduate (MSc) student. Graduate Program, Escola Paulista de Enfermagem, Federal University of São Paulo, UNIFESP, São Paulo, SP, Brazil.

${ }^{4}$ Graduate (PhD) student. Graduate Program, Escola Paulista de Enfermagem, Federal University of São Paulo, UNIFESP, São Paulo, SP, Brazil.
} 


\section{INTRODUCTION}

For a long time, oral tradition was the main way of knowledge sharing, since writing was, and it is until now, inaccessible to many people. In this tradition, we find stories that can be defined as a testimony transmitted orally from one generation to another, allowing beliefs and values to be perpetuated ${ }^{(1)}$.

Many times, we associate stories with tales, legends, and fables. However, family stories will be the focus in this study. Use of family stories is based on the fact that storytelling is a way of organizing thought, because stories present ideas and tell about perceptions and relationships. Therefore, it is a form of expression essential to the human being ${ }^{(1)}$.

We understand family as being a structure in continuous transformation. Thus, stories are told, retold, and transformed. Changes occur throughout the life cycle and the very facts of life, which require a constant elaboration (such as separation of parents, growth of children, leaving home, illness, aging, psychosis, death, etc), compose their plot.

For a better understanding of telling family stories, this study had systemic thinking as theoretical basis. The twentieth century was marked by notable scholars who provided multidisciplinary perspectives and different pathways for the production of knowledge in different areas, including health. During this period, systemic thinking showed to be a new view of the world in science and society, allowing a systemic conception of life and a holistic view of health ${ }^{(2)}$. Therefore, family is understood as an open system that interacts with other systems in society, including the health system.

Currently, public policies in Brazil seek to promote a new concept of health care and thus programs and strategies have been developed to extend this concept. The family (understood on the basis of the environment where it lives) has become an object of attention, as a care unit. Therefore, understanding the concept of family care has become something pertinent and relevant, which must consider issues related to territorial coverage, diversity, life situations, and cultural influences ${ }^{(3)}$.

In this study, definition of family health may therefore be described as a dynamics that maintains or changes the relative state of well-being, including elements of family systems such as biological, psychological, spiritual, and sociocultural aspects ${ }^{(4,5)}$. Given this reality, training professionals is necessary, so that they understand the family and their relationships, can act through practices that encourage change in paradigm on the basis of both systemic thinking and an environment characterized by new health needs, and understand the family as a care unit, focusing on practice and research in nursing ${ }^{(4,5)}$.
In this regard, recent studies show changes in the family as a support for assistance to patients and their families seen as a care unit ${ }^{(3-6)}$.

These changes lead to a need to expand the multidisciplinary view related to health education, promoting a rethink in practices of family nursing care. Thus, there is an investment in comprehensive care to the health of individuals and their families, expanding the strict idea of health as either absence of disease or promotion and protection of health ${ }^{(7)}$.

In recent years, teaching practice and research have been developed in the nursing-family dyad, allowing identification of learning strategies that put the undergraduate nursing student in touch with the family care theme ${ }^{(6-8)}$. Among the strategies, some instruments, such as genogram and eco-map, are used in nursing practice to act in family care. However, use of other practices to facilitate contact between the student and the family to be cared is necessary.

Thus, use of narrative has been investigated as a resource to produce knowledge in nursing ${ }^{(9)}$. In turn, personal history of those who will study the family has been scarcely explored.

The present study was intended to extend the action strategies of the undergraduate nursing student to "think" and "conduct" family care, using their family stories as a learning strategy based on perspective and reference of those involved in the teaching and learning process.

\section{OBJECTIVE}

To identify how undergraduate nursing students experience telling their own family stories, as a learning strategy to family care.

\section{METHODS}

This is a descriptive and qualitative study, whose project received approval from the Local Research Ethics Committee (Protocol No. 1966/10).

Eighteen female undergraduate nursing students from Escola Paulista de Enfermagem, Federal University of São Paulo (UNIFESP), participated in the study. Enrollment in the second year of the nursing course and attendance to classes of the elective discipline "Nursing assessment and intervention in the family at different times of its life cycle" were the criteria for inclusion of participants.

Data collection was performed at the Center for Assistance and Studies in Nursing, in the period OctNov 2010. Four meetings were held. They were composed of activities for sensitization, oral organization and written record of the reports, spaces for sharing 
family stories, and activities for group reflection. In the activities, participants relied on stories told by them to recover family feelings, meanings, beliefs, and values.

The meetings had a common general structure, and the activities were distributed into the following sequence: (1) Sensitization (to tell and build stories); (2) Storytelling and writing of family stories (to stimulate the oral and written expressions); (3) Sharing (to share feelings about the stories told and heard); and (4) Collective reflection (to give meaning to the stories).

In the first meeting, participants were sensitized on the "family stories" theme, watching a piece of a movie in which the protagonist reported phases of her life. Then, they were encouraged to tell to another participant of the group a story of her life that included her family. Then, the group interview was conducted with the following guiding questions: How was your experience of telling a story about your family? How important was it for you?

In the second meeting, each participant wrote a history about her family, including context and characters. Then, participants were divided into two subgroups, so that they could hear, tell, dialogue, and exchange experiences. At this stage, they were proposed to listen to other participants and reflect on how each family story was comparable to her life story, noting resonances and all that was common and different in the family stories. At the end, the group was invited to reflect on the following questions: How was for you organizing your story? How was for you hearing stories told by other participants?

At the third meeting, the family stories were recorded on media. This recording allowed individual choice of a musical background for each story that was written in the second meeting. At the end of recording, participants were invited to reflect based on the following guiding questions: Thinking about the stories you have heard, what is your perception about family? How this experience reflected on you as a nursing undergraduate student?

At the fourth meeting, a collective story was constructed, focusing on what was experienced/learned in the previous steps. The guiding question was: How was your experience in the group, both personally and as a future nurse in family care?

Data were analyzed with basis on a faithful transcription of each meeting, using content analysis as proposed by Bardin ${ }^{(10)}$. Analysis of study content was based on thematic or categorical analysis, which consists in identifying meaning units that constitute the narratives. The theme or category is the analytical basis to study meanings and beliefs ${ }^{(11)}$.

After analysis, the material was divided into categories, on the basis of themes that emerged during data collection. Thus, the material analyzed included: stories of the participants, which were constructed and edited in media; recording of the moments for group reflection after each workshop; general interview with guiding questions after each workshop, and collective history prepared by participants.

The narratives were identified with the letter "P" followed by a number, corresponding to each subject in the study to protect identity of participants.

\section{RESULTS}

Analysis of data allowed us to identify three categories: changes in perception and expansion of the family concept, with redefinition of ties; identification of similarities, beliefs, values, and rituals in family stories, and enhancement of active listening as a strategy to family care.

\section{Changes in perception and expansion of the concept of family, with redefinition of ties}

In this category, narratives and the recovery of emotions experienced by participants promoted organization of the concept of family and its contexts. The students described the meeting with feelings experienced in family, valued and recognized memories, realizing its importance and the feeling of belonging to different family formats, as recorded in narratives from P14, P3, and P10:

'My family is very traditional, but I've learned and am elaborating (even more telling my stories) that change is possible, and it's okay to leave some uses when it makes sense to people. Respect and love do not cease to exist when people have different wishes and/or opinions" (P14).

"In my story, I talked about a trip I made with my boyfriend and his family. For me, family is not only father and mother, but who's next, who helps, and gives support. I consider that my boyfriend's family, also my family" (P3).

"I learned that my family, although not completely united, makes me happy because I have by my side people I love, admire, and respect" (P10).

The participants also presented their perceptions about the importance of redefining ties with their original families or with a family member in particular, as expressed by P4, P16, and P12.

"With this story, I could see the importance and concern I have for my brother ... this story shows me how my family is united and how we love each other" (P4).

"For me, the meaning of this story is that I realize how much is good, important and comfortable knowing that there are people who love us and who are there to protect us in most diverse situations. My dad is someone very important, in whom I often get inspiration and with whom I am surprised with each story" (P16). 
"In these days, my mother began to tell a story, I did respect, understand the family context, know the family attitudes. Respecting and not being so sad, she did it because of that. I can better understand my parents, after they speak, I speak - is there anything else? Otherwise, I do not hear and there becomes a discussion” (P12).

\section{Identification of similarities, beliefs, values, and rituals in family stories}

This category is related to the ability of students to reflect on their own stories with basis on listening to the story of other person. It was possible to identify family similarities, beliefs, values, and rituals in the stories reported by P17 P01, and P11:

"I found this exchange very interesting. The story I told and they told, it was very interesting to see the similarities. To see that it is important to the other. What's in common? There are family complications, travels, difficulties, and little problems" (P17).

"Each story had a bit of my story. I found it interesting because just the story doesn't give you as much support as the feelings that come along with the story, overcoming, sadness, more by the feeling than by the story" (P1).

"In our group, in the stories ... someone talked about a problem experienced, something happened and after that family union and affection came. In all stories, there was union and affection; there is help, Christmas, union in a family. All families have difficulties, but all of them are united" (P11).

\section{Enhancement of active listening as a strategy to family care}

In this category, participants identified active listening as a trigger for care and a facilitator for approximation to the family, recognizing its importance as a strategy for care, because they reported to believe that it can be a means to favor communication and creation of ties, as described in the reports of P5, P2, and P4:

"As a future nurse, I will listen to many stories along the profession, (...) practicing with my family, I'll think that everyone who participated in the story will tell it differently, since for each person the same story has a different meaning" (P5).

"In terms of also listening, I think something everyone has learned, something was well focused here it was the importance of listening, and not interpreting what the other wants to talk, let bim talk and actually listen to, don't want to give your opinion and interpret your way" (P2).

"Hearing the stories, the main thing I learned was really to listen to, pay attention to others, understand, respect (...) I learned that everyone has a point of view on the story" (P4).

\section{DISCUSSION}

In recent decades, family care, among various skills of the nursing professional, has been revealed as another strategy to promote and protect health.
The family has always been considered as the mother cell of civilizations, because it plays a decisive role in formal and informal education and the development of human beings. Values, myths, and beliefs are transmitted through it, printing marks on generations who, in turn, are reflected in society.

In studies on family nursing, the current trend is to take care of the family as a system, as a care unit. Thus, nursing education requires teaching strategies aimed at autonomy and reflective practice on family care (and technical expertise). This justifies a deepening in the content of disciplines about family within academia ${ }^{(1,2)}$.

In the present study, relevant themes emerged in the nursing education and family care dyad. The results indicated that integration of personal and professional stories is important; we believe that contact with different understandings and individual and family experiences can contribute to a better professional performance in family nursing, as a care unit.

In this study, the nursing undergraduate students were invited to seek their family references by telling their stories and concluded that family is a unique concept, ie, each family builds its own history, its own myths, beliefs, and values. These are understood as a discursive formulation in which meaning and explanation of the reality experienced are expressed, on the basis of elements subjectively accessible to individuals, according to the culture in which they live. Family myths, as expressed in the stories told, have the function of printing the family brand, a heritage to be perpetuated ${ }^{(12)}$.

Reconstruction of stories and analysis of repeating relational patterns allowed broadening the view of the problem, and may bring into consciousness tools that helped draft conflicts and reframe contents.

By facilitating to the students a self-reflection about their families, we realize that the family concept is related to family dynamics, context, relationships, and ties. Transformations occur in this active and evolving context, which leads us to agree with the basic concept that family is evolving, continually being transformed, and organizing itself much more by affection ties than by consanguinity or traditional hierarchies ${ }^{(13)}$.

When thinking of the family as a system, it is understood that this is related to broader systems of community, society, and culture. Understanding family culture is important for any professional who intends to intervene on it and it involves understanding what constitutes a family and how it works.

People are experts in their own lives, with skills, beliefs, values, and resources that help reduce the influence of problems in their lives. However, contacting and enhancing these skills is necessary to make this happen, not valuing that they need to develop, but that they actually have. 
The work of "thinking" family, based on narratives, was shown to be as if it were something new for undergraduate students. People think and act with family members, but not with family as a whole, which suffers from changes and crises of each member ${ }^{(14)}$.

Therefore, "thinking" family is to understand the status of continuous change which it suffers. Furthermore, the life cycle is highlighted by being composed of crises and resolutions, ranging between balance and imbalance, as steps in the process of resolving the situation experienced.

Importantly, when the undergraduate students begin the practice of family care, they will not be alone. They will carry their inheritance, comprising family beliefs and values, which may help in the action plan, provided that personal experiences are understood as useful in daily nursing.

It was verified that as the participants told their stories and heard the story from others, they identified in their content moments of empowerment, crisis resilience, coping strategies, and a series of feelings that permeate these skills.

When people report a fact, they reorganize their experience, so that they have a consistent and meaningful order, giving meaning to the event. "A symbolic expression explains and teaches how to understand what is happening"(15). The stories we hear and tell situate us in the world where we live. They give meaning and value to the world and transform it as we also transform ourselves. Current and past stories are a way to reduce distances between places and people, giving a collective sense to what we do and what we are ${ }^{(1)}$.

In the learning context, this study shows that storytelling was an important tool in care practice. Several authors recognize the importance of listening to stories as a means to understand others and their context, a process of construction, maintenance, and diffusion of nursing knowledge. Within this perspective, we can say that the systemic approach is being employed because it facilitates understanding of the caregiver as part of the system, allowing the care process to be rebuilt together with those involved in $\mathrm{it}^{(1)}$.

In the practice of nursing care, the professional seeks to contribute to alleviation of suffering (an inevitable human condition for individuals and families), while looking for equilibrium, and pursuing wellness. Thus, listening carefully to what people and families want to tell, shows to be a good strategy to obtain information in planning care ${ }^{(15)}$.

It is worth mentioning that participants could perceive the difference between hearing and listening. When listening to the speech of another person, one may realize emotions and feelings that make the discourse unique. When the other's narrative is understood, it is possible to identify requests for help and broaden the understanding from the perspective of the other.

We believe that it was possible to sensitize participants to the importance of active listening as a form of care. Giving chance to experience through narrative is certainly an untapped source of knowledge, because this is based on short stories of everyday life, woven laboriously by time, and followed by reflection. Narratives are a rich material with which we construct the meanings and knowledge in nursing, which contribute to the development of nurses ${ }^{(15)}$.

Given the need to expand the ways by which nurses relate to family, we believe that establishing "active listening" is important. Currently, reports on daily life in the health area are common, in which professionals find it difficult to create an emotional bond ${ }^{(7)}$. In such cases, professional preparation and creating strategies to expand their ability to establish a bond of trust, can be favoring instruments to flowing relationships, within a space of respect, listening, and collaboration.

\section{CONCLUSIONS}

The results in this study confirm other studies in the nursing area, and encourage a more attentive listening to oneself and to the other, and a search for teaching strategies that can enlarge bond, understanding, and respect for diversity within a proposal for family care-centered comprehensive health care.

Thus, activities with family story are an important resource for individual and collective reflection, a fundamental aspect for nursing students to acquire new insight and learning about family care.

Therefore, family-based learning must consider context, relationships, and the process developed among participants in the existing situation. Further studies should be conducted to improve understanding of this practice and promote inclusion of family and its context in nursing care. 


\section{REFERENCES}

1. Ordaz O. O uso de narrativas como fonte de conhecimento em enfermagem. Pensar Enferm. 2011;15(1):70-87.

2. Bateson G. O padrão que une. In: Capra F editora. Sabedoria incomum: conversas com pessoas notáveis. São Paulo: Cutrix; 1988. p.59-73.

3. Brasil. Ministério da Saúde. Secretaria de Atenção à Saúde. Departamento de Atenção Básica.Política Nacional de Atenção Básica. 4a ed. Brasília(DF): Ministério da Saúde; 2007.

4. Cordeiro H. [Competences of nursing undergraduate students: nurses and nursing faculty perceptions]. Divulg Saúde Debate. 2000;(21):36-43. Portuguese.

5. Wacharasin C, Theinpichet S. Family nursing practice, education, and research: what is happening in Thailand? J Fam Nurs. 2008 Nov;14(4):429-35.

6. Wernet M, Angelo M. Moving to fhe Family:Giving a new definition for fhe family and fhe care. Rev Esc Enferm USP. 2003;37(1):19-25.

7. Figueiredo MH. Enfermagem de famillia: um contexto do cuidar [dissertação]. Porto: Universidade do Porto; 2009. 521 p.

8. Horta AL, Caldeira NH. [A nursing perspective on community care: for families]. Acta Paul Enferm. 2011;24(2):165-71. Portuguese.

9. Silva DG, Trentini M. Narrativas como Técnica de Pesquisa em Enfermagem. Rev Latinoam Enferm. 2002; 10(3):423-32.

10. Bardin L. Análise de conteúdo. Lisboa: Edições 70;1977. 226p.

11. Minayo MC. O desafio do conhecimento : pesquisa qualitativa em saúde. São Paulo: Hucitec, 2008.

12. Sarti CA. A família como ordem simbólica. Psicologia USP. 2004;15(3):11-28.

13. Cerveny CM, Berthoud CM. Ciclo vital da família brasileira. In: Osório LC; Valle ME. Manual de terapia familiar. Porto Alegre: Artmed, 2008. p. 25-37.

14. Silva DG, Trentini M. Narrativas como técnica de pesquisa em enfermagem. Rev Latinoam Enferm. 2002;10(3):423-32.

15. Leight SB. Starry night: using story to inform aesthetic knowing in women's health nursing. J Adv Nurs. 2002;37(1):108-14. 